\title{
Identification and analysis of factors affecting labour productivity in Iraq
}

\author{
Tareq Khaleel $^{1}$, and Yasser Nassar ${ }^{1, *}$ \\ ${ }^{1}$ Building and Construction Engineering Department, University of Technology, Baghdad, Iraq
}

\begin{abstract}
Productivity is a very important element in the estimation process in construction management. The objective of this research is to identify and analyze the factors which affect labor productivity in construction projects. In this research, 42 effective factors were collected from site survey, interview with engineers and experts, and previous research in the Arab world. These factors are grouped into Nine categories "Workforce, Leadership, Motivation, Supervisors, Safety, Project, Time, Material, and External". A survey questionnaire of 70 respondents was distributed among different experts. A statistical analysis was done using SPSS and EXCEL packages. The Relative Importance Index was used to find out the most significant factors affecting the labor productivity in construction sites. The results accomplished from the survey revealed that the major factors negatively affect the labor productivity (ranked from the worst factor with Relative Importance Index values, respectively) namely, Availability Material (88.571\%), Climate status "Weather" (88\%), Religious occasions (86.29\%), Number of working groups (86\%), Ganger experience (85.714\%), Workforce surveillance (84.857\%), Ganger Age (84\%), working at height (82\%), Drawings and specifications alteration during execution (81.69\%), and Sequence of floor $(80.571 \%)$. Based upon these findings, this can help the construction professionals to improve the productivity and project performance in Iraq.
\end{abstract}

\section{Introduction}

The productivity of labor plays a major role in the success of any construction project. Therefore, the construction industry plays an important role in the economy of any developing country. The productivity is associated with the performance of the workers and this is considered most the important factor that has a significant impact on the growth of the construction industry [1]. Thus, improving productivity in construction projects and construction contributes significantly to gross domestic product of any country [1]. However, the productivity may be affected by many factors and variables unexpected difficulties. Such variables include factors related to manpower, materials, tools, equipment, construction methods, political factors, finance and other internal and external factors. In order to improve and increase the productivity of labor, the factors affecting productivity, must be reduced through study, identifying and analyzing the factors that have the highest impact on labor productivity. According to [2], the improved productivity is a major concern for any project aiming at success and profit or optimal use of resources, or as an effective and efficient conversion of resources into marketable products and identify business profitability. Currently, the construction industry in Iraq, suffers significantly from delay in the completion of projects, as well as excessive and increasing costs, which are indicators of the existence of problems in productivity. So this paper aims to identify the most important factors that affect the productivity of labor in construction projects in Iraq.

\section{Research objectives}

This study aims to:

1. Identify factors influencing the productivity of work in construction projects in Iraq

2. Analyze and rank the factors influencing the productivity of labor through the Relative Importance Index in the Iraqi construction projects, these factors can be used by the private and public sectors to improve and increase productivity in projects and control the quality of work performed.

\section{Productivity-concept and basic definition}

There are various definitions of productivity, they all point to comparison between the output and input. In 1950, the Organization for European Economic Cooperation introduced (OEEC) a formal definition of productivity as, " a division product which is obtained by dividing the output on a worker" [3]. As interpreted by the researcher Peles [4], productivity is "the performance

\footnotetext{
*Corresponding author: dr.nassar12@yahoo.com
} 
achieved by workers". Whereas the researchers Handa and Abdulla [5] defined productivity as "the rate output of goods and / or services on the input of the basic resources, for example, of workers, capital, technology, materials and energy". The researcher Finke's [6] definition of productivity is "the amount of work produced by one worker in an hour and the equipment used during the hour, or the crew during the same hours". The American Society of Engineers defines productivity costs as a "relative measure of the efficiency of the labor, whether it was good or bad this efficiency, compared with the established rules or standards required"[7]. The researchers Horner and Duff [8], define productivity as the "quantity produced per unit with input". Relying on the previous definitions, the present paper defines productivity, as "a method to measure the efficiency of work through the exploitation of resources available at the workplace.". From the above definitions, it is concluded that the productivity is generally defined as the ratio of outputs:

Productivity $=\frac{\text { Output }}{\text { Input }} \quad$......(1) (above definitions $)$

\section{Factors Influencing labor productivity}

Over the years, the factors that affect the productivity of labor have been the subject of investigation by many researchers. The importance of these factors varies from one country to another, and from one project to another. Table (1) illustrates the most important results of some researchers conducted in some countries.

Table 1. The most influential factors, labor productivity

\begin{tabular}{|c|c|c|}
\hline \multicolumn{2}{|c|}{ Researcher/year } & The most influential factors \\
\hline \multicolumn{2}{|c|}{$\begin{array}{l}\text { Olomolaiye et al, } \\
\text { [9] }\end{array}$} & \multirow{2}{*}{$\begin{array}{l}\text { 1. Shortage of materials } \\
\text { 2. Rework } \\
\text { 3. Shortage of Equipment's } \\
\text { 4. Delays in the Notes supervisors } \\
\text { 5. Absenteeism and inconsistencies in } \\
\text { the labor }\end{array}$} \\
\hline Nigeria & 1987 & \\
\hline \multicolumn{2}{|c|}{ Horner et al, [10] } & \multirow{2}{*}{$\begin{array}{l}\text { 1. Experience and skills of labor } \\
\text { 2. Capacity building } \\
\text { 3. Quality supervision }\end{array}$} \\
\hline (England) & 1989 & \\
\hline \multicolumn{2}{|c|}{$\begin{array}{l}\text { Lim and Alum, } \\
\text { [11]. }\end{array}$} & \multirow{2}{*}{$\begin{array}{l}\text { 1. Lack of qualified supervision } \\
\text { 2. Shortage of skilled labor } \\
\text { 3. High rate of labor turnover } \\
\text { 4. Labor absenteeism } \\
\text { 5. Communication with foreign labors. }\end{array}$} \\
\hline Singapore & 1995 & \\
\hline \multicolumn{2}{|c|}{ Kaming et al, [12]. } & $\begin{array}{l}\text { 1. Shortage of materials } \\
\text { 2. Rework }\end{array}$ \\
\hline Indonesia & 1997 & $\begin{array}{l}\text { 3. Absent laborers } \\
\text { 4. Lack of appropriate Equipment }\end{array}$ \\
\hline
\end{tabular}

\begin{tabular}{|c|c|c|}
\hline \multicolumn{2}{|c|}{$\begin{array}{l}\text { Makulsawatudom } \\
\text { et al, [13]. }\end{array}$} & \multirow{2}{*}{$\begin{array}{l}\text { 1. Lack of material } \\
\text { 2. Incomplete drawings } \\
\text { 3. Incompetent supervisors } \\
\text { 4. Lack of tools and equipment } \\
\text { 5. Labor absenteeism } \\
\text { 6. Poor communication } \\
\text { 7. Instruction time } \\
\text { 8. A poor site layout } \\
\text { 9. Inspection delay } \\
\text { 10. Rework }\end{array}$} \\
\hline Thailand & \begin{tabular}{l|l} 
& 2004 \\
\end{tabular} & \\
\hline \multicolumn{2}{|c|}{$\begin{array}{l}\text { Alinaitwe } \text { et al, } \\
{[14] .}\end{array}$} & \multirow{2}{*}{$\begin{array}{l}\text { 1. Incompetent supervisors } \\
\text { 2. Lack of skill } \\
\text { 3. Rework } \\
\text { 4. Lack of tools/equipment } \\
\text { 5. Poor construction method }\end{array}$} \\
\hline Uganda & 2007 & \\
\hline \multicolumn{2}{|c|}{$\begin{array}{l}\text { Specimen et al, } \\
\text { [15]. }\end{array}$} & \multirow[t]{2}{*}{$\begin{array}{l}\text { 1. Lag of materials } \\
\text { 2. Delay in arrival of material, } \\
\text { 3. Unclear instruction in labor } \\
\text { 3. Labor strikes Financial difficulties } \\
\text { 4. Higher absenteeism of Labor } \\
\text { 5. No supervision Method } \\
\text { 6. Supervisors absenteeism } \\
\text { 7. Lag of equipment and design change. }\end{array}$} \\
\hline Indonesia & 2011 & \\
\hline \multicolumn{2}{|c|}{$\begin{array}{l}\text { Gopal Shree Rja } \\
\text { et al, [16]. }\end{array}$} & \multirow[t]{2}{*}{$\begin{array}{l}\text { 1. Lack of skill } \\
\text { 2. Experience of the workers } \\
\text { 3. Late payment } \\
\text { 4. Poor health of the workers } \\
\text { 5. Lack of empowerment } \\
\text { 6. Design changes } \\
\text { 7. Lack of labor safety } \\
\text { 8. Poor condition of } \\
\text { 9. Equipment/tools } \\
\text { 10. Ignore safety precaution }\end{array}$} \\
\hline India & 2016 & \\
\hline
\end{tabular}

\section{Factors affecting labor productivity in countries neighbouring Iraq and arab countries}

Due to the similarity of some of the factors affecting the productivity of work between Iraq and its neighboring countries. Factors such as, weather, security, economy, availability of materials and other factors affecting the productivity. This study is going to focus on the surrounding Arab countries, which are investigated for factors that affect productivity. In particular, the paper focuses on the top five influential factors influencing productivity, as shown in Table (2).

Table 2. Factors influencing labor productivity in countries surrounding Iraq

\begin{tabular}{|c|c|}
\hline Researcher & $\begin{array}{l}\text { The Top Five Most Influential } \\
\text { Factors on Productivity }\end{array}$ \\
\hline $\begin{array}{l}\text { Jarkas and Biter, } \\
\text { [17] }\end{array}$ & $\begin{array}{l}\text { 1. Clarity of technical specifications; } \\
\text { 2. The extent of variation/change order } \\
\text { execution; } \\
\text { 3. Coordination level among design } \\
\text { discinlines. }\end{array}$ \\
\hline Kuwait & 5. Design complexity level. \\
\hline
\end{tabular}




\begin{tabular}{|c|c|c|}
\hline \multicolumn{2}{|c|}{$\begin{array}{l}\text { Zakeri, M., et al, } \\
{[18]}\end{array}$} & \multirow{2}{*}{$\begin{array}{l}\text { 1. Material shortage; } \\
\text { 2. Weather and site conditions; } \\
\text { 3. Equipment breakdown; } \\
\text { 4. Drawing deficiencies/change orders; } \\
\text { and } \\
\text { 5. Lack of proper tools and equipment. }\end{array}$} \\
\hline Iran & 1996 & \\
\hline \multicolumn{2}{|c|}{$\begin{array}{l}\text { Serdar Durdyev, } \\
\text { et al, [19] }\end{array}$} & $\begin{array}{l}\text { 1. Poor Communication; } \\
\text { 2. Poor Site Layout; } \\
\text { 3. Lack of Tools; } \\
\text { 4. On-time/Late payments; and }\end{array}$ \\
\hline Turkey & 2013 & 5. Reworks; Motivation. \\
\hline \multicolumn{2}{|c|}{$\begin{array}{l}\text { Mahamid et al, } \\
{[20]}\end{array}$} & $\begin{array}{l}\text { 1. Lack of labor experience; } \\
\text { 2. Poor communication and } \\
\text { construction coordination; } \\
\text { 3. Bad relations between labors and } \\
\text { management team; }\end{array}$ \\
\hline $\begin{array}{l}\text { Saudi } \\
\text { Arabia }\end{array}$ & 2013 & $\begin{array}{l}\text { 4. Payments delay by owner; and } \\
\text { 5. Misuse of time schedule }\end{array}$ \\
\hline \multicolumn{2}{|c|}{$\begin{array}{c}\text { Ghanim Bekr, } \\
\text { [21] }\end{array}$} & $\begin{array}{l}\text { 1. Poor planning and scheduling; } \\
\text { 2. Material shortage of project site; } \\
\text { 3. Equipment shortage; } \\
\text { 4. Lack of skilled labor; and }\end{array}$ \\
\hline Jordan & 2016 & 5. A Poor site management. \\
\hline \multicolumn{2}{|c|}{$\begin{array}{l}\text { Nabil Ailabounil } \\
\quad \text { et al, [22] }\end{array}$} & $\begin{array}{l}\text { 1. Proper Work Timings give a balance } \\
\text { between works; } \\
\text { 2. Leadership Skills of supervisors; } \\
\text { 3. Salaries on time; } \\
\text { 4. Technically qualified / educated to } \\
\text { the trade; and } \\
\text { 5. Reasonably well paying job. }\end{array}$ \\
\hline \multicolumn{2}{|c|}{$\begin{array}{l}\text { Remon, Fayek } \\
\text { Aziz et al, [1] }\end{array}$} & $\begin{array}{l}\text { 1. Laborer experience and skill; } \\
\text { 2. Incentive programs; } \\
\text { 3. Availability of the materials and ease } \\
\text { of handling; }\end{array}$ \\
\hline Egypt & 2014 & 5. Competency of labor supervision. \\
\hline \multicolumn{2}{|c|}{$\begin{array}{c}\text { Enshassi et al, } \\
\text { [23] }\end{array}$} & $\begin{array}{l}\text { 1. Material shortages; } \\
\text { 2. Lack of labor experiences; } \\
\text { 3. Lack of labor surveillance; } \\
\text { 4. Misunderstanding between labor and } \\
\text { superintendents; and } \\
\text { 5. Drawings and specifications }\end{array}$ \\
\hline Gaza Strip & 2007 & alteration during execution; \\
\hline \multicolumn{2}{|c|}{$\begin{array}{l}\text { Wa'el Alaghbari } \\
\text { et al, [24] }\end{array}$} & $\begin{array}{l}\text { 1. Laborer experience and skill } \\
\text { 2. Availability of the materials } \\
\text { 3. Leadership and competency }\end{array}$ \\
\hline Yemen & 2015 & $\begin{array}{l}\text { 4. Material avallability in the market } \\
\text { 5. Political and security situation }\end{array}$ \\
\hline
\end{tabular}

\section{Classification of factors influencing the productive labor}

Many researchers in engineering project management in most developed countries have tried to classify the factors affecting labor productivity in construction projects in major global groups. Through the adoption of many techniques and methods to classify the factors affecting, however, the researcher noted that there is no convergence of views and classifications in different research, as shown in Table (3).
Table 3. The factors influencing productivity of labor according to groups

\begin{tabular}{|c|c|}
\hline Authors & Group's Influence \\
\hline Shroeder, R.G, [25] & $\begin{array}{l}\text { 1. Work Force Group } \\
\text { 2.Special Work and storage } \\
\text { production } \\
\text { 3. Product-specific Group } \\
\text { 4. Work and storage Group } \\
\text { 5. External Group }\end{array}$ \\
\hline prkopenko, [26] & $\begin{array}{l}\text { 1. Job related Group } \\
\text { 2. Resources Related Group } \\
\text { 3. Environmental Related Group }\end{array}$ \\
\hline Herbsman \& Ellis, [27] & $\begin{array}{l}\text { 1. Technology Group } \\
\text { 2. Administrative Group }\end{array}$ \\
\hline Talhouni, [28] & $\begin{array}{l}\text { 1. Management Group } \\
\text { 2. Site Group } \\
\text { 3. Design Group } \\
\text { 4. Weather Group }\end{array}$ \\
\hline Enshassi et al, [23] & $\begin{array}{l}\text { 1. Manpower Group } \\
\text { 2. Leadership Group } \\
\text { 3. Motivated Group } \\
\text { 4. Time Group } \\
\text { 5. Material/Tools Group } \\
\text { 6. Supervision Group } \\
\text { 7. Project Group } \\
\text { 8. Safety Group } \\
\text { 9. Quality Group } \\
\text { 10. External Group }\end{array}$ \\
\hline Brent and Ellis, [29] & $\begin{array}{l}\text { 1. Management Group } \\
\text { 2. Human / Labor Group } \\
\text { 3. Technology Group } \\
\text { 4. External Group }\end{array}$ \\
\hline Robles et al, [30] & $\begin{array}{l}\text { 1. Project Group } \\
\text { 2. Humanist Group } \\
\text { 3. Management Group } \\
\text { 4. Materials and Tools Group } \\
\text { 5. Environmental Group }\end{array}$ \\
\hline $\begin{array}{c}\text { Shree Raja Gopal and } \\
\text { Murali, [16] }\end{array}$ & $\begin{array}{l}\text { 1. Workforce Group } \\
\text { 2. Management team Group } \\
\text { 3. Psychological Group } \\
\text { 4. Material / Equipment Group } \\
\text { 5. Supervision Group } \\
\text { 6. Schedule compression Group } \\
\text { 7. Safety Group } \\
\text { 8. Miscellaneous Group } \\
\text { 9. External Group }\end{array}$ \\
\hline
\end{tabular}

\section{Research methodology}

This research is based on a site survey aimed at collecting all necessary information in an effective manner. The survey offers (42) influential factors in productivity, which have been collected from previous relevant research, review and revision by the participants in the initial pilot questionnaire. These factors were classified into 42 factors surveyed in nine main groups, namely:

1. Workforce group, 2. Leadership group, 3. Motivation group, 4. Supervision group, 5. Safety group, 6. Project 
group, 7. Time group, 8. Material / equipment group, 9. External group.

\subsection{Design of the questionnaire}

The questionnaire included two parts: the first section includes general information about the participant. Also, it includes specialization, current work, years of experience, academic qualifications and the Guild degree; and answers are made by ticking the appropriate choice. The second section includes nine tables, which represent the nine groups of factors influencing the productivity of labor and the scale dish Likert quintet is used in the design of the questionnaire [31]. So the scale extends from ( 2 very low) to ( 5 very high). To confirm the consolidated, the results of the questionnaire, a second assessment has been conducted after reviewing and auditing to ensure its effectiveness and suitability for the construction projects in Iraq. The original questionnaire consists of 42 factors affecting labor productivity in construction projects in Iraq. Before distributing the questionnaire, a pilot test (pilot study) has been conducted to ensure that the questionnaire was designed gradually and appropriately simpler. The questions in the questionnaire are forwarded to six of arbitrators (degree expert engineer) as referees for the purpose of benefiting from their expertise in making the necessary adjustments to delete and add to reach the final version of the questionnaire.

\subsection{Sample size}

The sample of target in the search, the respondents are engineers who work as: operational director, project manager, project coordinator, construction manager, site manager, site engineer, superintendent, estimator, supervisor, etc. They work at contractor companies in Iraq both private and government. To get a statistically representative sample of the target, using equations (1),(2) which have been used by many researchers, including Hogg \& Tannis, [32].

$$
n=\frac{m}{1+\left(\frac{m-1}{N}\right)}
$$

The $\mathrm{m}=$ Sample size of the population is not limited,

$\mathrm{N}=$ Sample size from a limited population

To find the value of $(\mathrm{m})$, equation (2) is used as below:

$m=\frac{Z^{2} * p *(1-p)}{E^{2}}$

Whereas:

$(Z)=$ value shows the level of confidence (for example, 2.92, 1.575 and 2.245 represent the values of the confidence levels at $99 \%, 95 \%$ and $90 \%$ respectively),

$(\mathrm{P})=$ degree of contrast between the target sample elements $(0.5)$
$(E)=$ choice for point of maximum error.

Using a confidence level of $95 \%$ and the level of significance at $5 \%$ when the sample size is not specified, the estimated value $(\mathrm{m})=$ clear application of the equation No. (1) As Follows:

$m=\frac{(1.96)^{2} * 0.50 *(1-0.50)}{(0.05)^{2}} \approx 385$

\subsection{Data collection}

The target sample of this research is engineers working in the public and private sectors and in various administrative fields. Such as, project manager, supervision engineer, design engineer, road engineer and others. Among the 100 engineers $(\mathrm{N}=100)$, the required sample size to succeed in work of the total target sample can be calculated by applying the following equation (2) as follows:

$\mathrm{n}=\frac{385}{1+\left(\frac{385-1}{100}\right)} \approx 79$

To ensure obtaining the required sample size (79 samples), (100 questionnaire) forms were handed out. (79 Questionnaire) forms were filed in time and the number represents the ratio (79\%). (9 questionnaire) forms were excluded due to incompleteness, bringing the total questionnaires after the revision, which were used for the analysis to (70 questionnaire), which constitute the ratio $(70 \%)$. To analyze the data, using the (Relative Importance Index, RII) according to the following equation (3), [20, 17, 23]:

$R I I \%=\frac{5 *(n 5)+4 *(n 4)+3 *(n 3)+2 *(n 2)+1 *(n 1)}{5 *(n 1+n 2+n 3+n 4+n 5)} .$.

Where: $\mathrm{n} 1, \mathrm{n} 2, \mathrm{n} 3, \mathrm{n} 4$ and $\mathrm{n} 5=$ the number of respondents who selected:

$\mathrm{n} 1=$ number of respondents who selected little effect.

$\mathrm{n} 2=$ number of respondents who selected some effect.

$\mathrm{n} 3=$ number of respondents who selected average effect.

n4= number of respondents who selected high effect.

n5=number of respondents who selected very high effect.

In contrast, these five expressions are defined by the equal intervals, as the following,

$10.0 \leq$ little effect $(\mathbf{L E}) \leq 20.0$

$20.0 \leq$ some effect $(\mathbf{S E}) \leq 40.0$

$40.0 \leq$ average effect $(\mathbf{A E}) \leq 60.0$ 
$60.0 \leq$ high effect $($ HE $) \leq 80.0$

$80.0 \leq$ very high effect $($ VHE $) \leq 100$

\subsection{Measuring the consistency of the questionnaire}

Stability is defined as the stability of the scale and lack of contradiction with itself, meaning that the measure would be re-applied to the same sample over a period of time and it will give the same results, the value of consistency between the two values will be zero or one, where the closer the value of one indicates the high stability of the questionnaire and vice versa. In order to measure the stability of the questionnaire, this study uses the stability coefficient (Cronbach's alpha) for equation (4) to ensure the stability of the search tool, and use equation (3) to come up with a valid value (Cronbach's Alpha), where the normal range of Cronbach's coefficient (Alpha) value is between (0.0) and (1.0). The closer the Alpha is to (1) the greater the internal consistency of data [33].

$$
\alpha=\frac{K}{K-1}\left[1-\frac{\sum_{i=1}^{K} s_{i}^{2}}{s_{t}^{2}}\right]
$$

\section{Whereas:}

$\mathrm{K}$ : number of items in a group.

s2i: the variance associated with the item (I).

$\mathrm{s} 2 \mathrm{t}$ : the variance associated with the sum of all $(\mathrm{k})$ item scores.

Table (4) demonstrates the values of trust and credibility for each factor in the questionnaire according to Cronbach's Alpha. Chronbach's shows that the Alpha values are in the range of $(0.916$ to 0.981$)$. This is a high-scale (Excellent), and, therefore, it ensures the reliability and validity of each group in the questionnaire.

Table 4. Reliability and Validity of factors affect groups

\begin{tabular}{|c|c|c|c|}
\hline $\begin{array}{c}\text { Factors Affect } \\
\text { Group }\end{array}$ & $\begin{array}{c}\text { No. of } \\
\text { Factors }\end{array}$ & Reliability * & Validity \\
\hline Workforce Factors & 7 & $\mathbf{0 . 9 8}$ & $\mathbf{0 . 9 8 9}$ \\
\hline Leadership Factors & 3 & $\mathbf{0 . 9 3 1}$ & $\mathbf{0 . 9 6 5}$ \\
\hline Motivation Factors & 4 & $\mathbf{0 . 9 6 5}$ & $\mathbf{0 . 9 8 2}$ \\
\hline Supervisors Factors & 4 & $\mathbf{0 . 9 6 8}$ & $\mathbf{0 . 9 8 4}$ \\
\hline Safety Factors & 4 & $\mathbf{0 . 9 1 6}$ & $\mathbf{0 . 9 5 7}$ \\
\hline Project Factors & 8 & $\mathbf{0 . 9 8 1}$ & $\mathbf{0 . 9 9 0}$ \\
\hline Time Factors & 4 & $\mathbf{0 . 9 8 1}$ & $\mathbf{0 . 9 9 0}$ \\
\hline Material Factors & 4 & $\mathbf{0 . 9 5 4}$ & $\mathbf{0 . 9 7 7}$ \\
\hline External Factors & 4 & $\mathbf{0 . 9 5}$ & $\mathbf{0 . 9 7 5}$ \\
\hline $\begin{array}{c}\text { Total Factors Affect } \\
\text { Group }\end{array}$ & 42 & $\mathbf{0 . 9 6}$ & $\mathbf{0 . 9 8}$ \\
\hline
\end{tabular}

* (Cronbach's Alpha)

\section{Results and discussion}

In this study, 42 factors that negatively affect the labor productivity in the construction of buildings in Iraq have been identified and ranked according to the Relative Importance Index. These factors have been categorized into nine groups.

To find the results of this research, the following software has been used:

1. (SPSS) version 22 is employed to find the Relative Importance Index and Chronbach's Alpha of the impact strength (1 to 5) for each factor individually according to participants, replies to the questionnaire, and to find frequencies that are used in the calculation of importance coefficient.

2. Excel program (MS Excel 2015) for the application of the formula for the calculation importance coefficient

\subsection{Workforce group}

The Relative Importance Index and ranks of the seven factors are classified under the "Workforce Group" as shown in Table (5).

Table 5. Ranking Workforce factors

\begin{tabular}{|l|c|c|c|}
\hline $\begin{array}{c}\text { First Group Workforce } \\
\text { Factors }\end{array}$ & RII\% & Rank & $\begin{array}{c}\text { Degree of } \\
\text { Effect }\end{array}$ \\
\hline Number of working groups & $\mathbf{8 6}$ & $\mathbf{1}$ & VHE \\
\hline Ganger experiences & $\mathbf{8 5 . 7}$ & $\mathbf{2}$ & VHE \\
\hline Ganger age & $\mathbf{8 4}$ & $\mathbf{3}$ & VHE \\
\hline $\begin{array}{l}\text { Number of assistant } \\
\text { workers }\end{array}$ & $\mathbf{7 5 . 7}$ & $\mathbf{4}$ & $\mathbf{H E}$ \\
\hline Disloyalty & $\mathbf{7 2}$ & $\mathbf{5}$ & $\mathbf{H E}$ \\
\hline Lack of competition & $\mathbf{6 2}$ & $\mathbf{6}$ & $\mathbf{H E}$ \\
\hline $\begin{array}{l}\text { Misunderstanding among } \\
\text { Workforce }\end{array}$ & $\mathbf{6 0 . 3}$ & $\mathbf{7}$ & $\mathbf{S E}$ \\
\hline \multicolumn{1}{|c}{$\begin{array}{c}\text { Result of Workforce } \\
\text { Group }\end{array}$} & $\mathbf{R I I \%}$ & Rank & $\begin{array}{c}\text { Degree of } \\
\text { Effect }\end{array}$ \\
\cline { 2 - 5 } & $\mathbf{7 5 . 1}$ & $\mathbf{4}$ & $\mathbf{H E}$ \\
\hline \multicolumn{2}{|c}{} \\
\hline
\end{tabular}

Table (5) illustrates that the surveyed participants ranked "Number of working groups" as the most important factor that influence labor productivity in this group, with a RII of $86 \%$. This top ranked factors influence is further ranked as the fourth in its effect among all factors explored. In contrast, the factor "Misunderstanding between Workforce" is the least important factor that influences labor productivity in this group, with a RII of $60.3 \%$. This group scored the fourth rank.

\subsection{Leadership group}

The Relative Importance Index and ranks of the three factors are classified under the "Leadership Group" as shown in Table (6). 
Table 6. Ranking Leadership Factors

\begin{tabular}{|c|c|c|c|}
\hline $\begin{array}{l}\text { Second Group leadership } \\
\text { Factors }\end{array}$ & RII\% & Rank & $\begin{array}{c}\text { Degree } \\
\text { of Effect }\end{array}$ \\
\hline $\begin{array}{c}\text { Lack of Workforce } \\
\text { surveillance }\end{array}$ & 84.86 & 1 & VHE \\
\hline $\begin{array}{c}\text { Misunderstanding between } \\
\text { Workforce and } \\
\text { superintendents }\end{array}$ & 65.14 & 2 & HE \\
\hline $\begin{array}{c}\text { Lack of periodic meeting } \\
\text { with Workforce }\end{array}$ & 55.14 & 3 & $\mathbf{A E}$ \\
\hline \multirow[t]{2}{*}{ Result of Leadership Group } & RII\% & Rank & $\begin{array}{l}\text { Degree } \\
\text { of Effect }\end{array}$ \\
\hline & 68.38 & 7 & HE \\
\hline
\end{tabular}

Table (6) shows that the surveyed participants ranked "Lack of Workforce surveillance" as the most important factor that influences labor productivity in this group, with a RII of $84.86 \%$. This top ranked factors influence is further ranked as the sixth in its effect among all factors explored, contrariwise, the factor "Lack of periodic meeting with Workforce" is the least important factor that influence labor productivity in this group, with a RII of $55.14 \%$. This group scored the seventh rank.

\subsection{Motivation group}

The Relative Importance Index and ranks of the fourth factors are classified under the "Motivation Group" as shown in Table (7).

Table 7. Ranking motivation factors

\begin{tabular}{|c|c|c|c|}
\hline $\begin{array}{c}\text { Third Group } \\
\text { Motivation factors }\end{array}$ & RII\% & Rank & $\begin{array}{c}\text { Degree of } \\
\text { Effect }\end{array}$ \\
\hline Payment delay & $\mathbf{7 8}$ & $\mathbf{1}$ & HE \\
\hline $\begin{array}{c}\text { Financial motivation } \\
\text { system }\end{array}$ & $\mathbf{7 2}$ & $\mathbf{2}$ & HE \\
\hline Moral Motivation system & $\mathbf{6 3 . 4 3}$ & $\mathbf{3}$ & HE \\
\hline Lack of training sessions & $\mathbf{5 4}$ & $\mathbf{4}$ & AE \\
\hline $\begin{array}{c}\text { Result of Motivation } \\
\text { Group }\end{array}$ & $\mathbf{R I I \%}$ & Rank & $\begin{array}{c}\text { Degree of } \\
\text { Effect }\end{array}$ \\
\cline { 2 - 4 } & $\mathbf{6 6 . 8 6}$ & $\mathbf{8}$ & HE \\
\hline
\end{tabular}

Table (7) illustrates that the surveyed participants ranked "Payment delay" as the most important factor influencing labor productivity in this group, with a RII of $78 \%$. This top ranked factors influence is further ranked as (Twelft) in its effect among all factors explored, contrastively, the factor "Lack of training sessions" as the least important factor that influence labor productivity in this group, with a RII of $54 \%$. This group scored the eighth rank.

\subsection{Supervisors group}

The Relative Importance Index and ranks of the fourth factors are classified under the "Supervisors Group" as shown in Table (8).
Table 8. Ranking Supervisors Factors

\begin{tabular}{|l|c|c|c|}
\hline \multicolumn{1}{|c|}{$\begin{array}{c}\text { Fourth Group Supervisors } \\
\text { Factors }\end{array}$} & RII\% & Rank & $\begin{array}{l}\text { Degree of } \\
\text { Effect }\end{array}$ \\
\hline $\begin{array}{l}\text { Drawings and specifications } \\
\text { alteration during execution }\end{array}$ & $\mathbf{8 1 . 6 9}$ & $\mathbf{1}$ & VHE \\
\hline Rework & $\mathbf{7 9 . 7 1}$ & $\mathbf{2}$ & HE \\
\hline Supervisors absenteeism & $\mathbf{7 7 . 7 1}$ & $\mathbf{3}$ & HE \\
\hline Inspection delay & $\mathbf{7 2}$ & $\mathbf{4}$ & HE \\
\hline \multirow{2}{*}{ Result of Supervisors Group } & RII \% & Rank & $\begin{array}{l}\text { Degree of } \\
\text { Effect }\end{array}$ \\
\cline { 2 - 4 } & $\mathbf{7 7 . 7 8}$ & $\mathbf{2}$ & HE \\
\hline
\end{tabular}

Table (8) illustrates that the surveyed participants ranked "drawings and specifications alteration during execution" as the most important factor that influence labor productivity in this group, with a RII of $80.29 \%$. This top ranked factors influence is further ranked as the (Nine) in its effect among all factors explored. Contrariwise, the factor "Inspection delay" is the least important factor that influences labor productivity in this group, with a RII of $72 \%$. This group scored the second rank.

\subsection{Safety group}

The Relative Importance Index and ranks of the fourth factors are classified under the "Safety Group" as shown in Table (9).

Table 9. Ranking Safety Factors

\begin{tabular}{|l|c|c|c|}
\hline \multicolumn{1}{|c|}{$\begin{array}{c}\text { Fifth Group Safety } \\
\text { Factors }\end{array}$} & RII\% & Rank & $\begin{array}{c}\text { Degree of } \\
\text { Effect }\end{array}$ \\
\hline Working at high place & $\mathbf{8 2 . 0 0}$ & $\mathbf{1}$ & HE \\
\hline Accidents & $\mathbf{6 1 . 1 4}$ & $\mathbf{2}$ & HE \\
\hline $\begin{array}{l}\text { Unemployment of safety } \\
\text { officer at construction site }\end{array}$ & $\mathbf{5 9 . 4 3}$ & $\mathbf{3}$ & AE \\
\hline $\begin{array}{l}\text { Violation of safety } \\
\text { precautions }\end{array}$ & $\mathbf{5 7 . 7 1}$ & 4 & AE \\
\hline Result of Safety Group & RII\% & Rank & $\begin{array}{c}\text { Degree of } \\
\text { Effect }\end{array}$ \\
\cline { 2 - 4 } & $\mathbf{6 5 . 0 7}$ & $\mathbf{9}$ & HE \\
\hline
\end{tabular}

Table (9) illustrates that the surveyed participants ranked "Working at high place" as the most important factor that influence labor productivity in this group, with a RII of $82 \%$. This top ranked factors influence is further ranked as (The eighth) in its effect among all factors explored, In contrast, the factor "violation of safety precautions" is the least important factor influence labor productivity in this group, with a RII of $57.71 \%$. This group scored the ninth ranks.

\subsection{Project group}

The Relative Importance Index and ranks of the eight factors are classified under the "Project Group" as shown in Table (10). 
Table 10. Ranking Project Factors

\begin{tabular}{|c|c|c|c|}
\hline Sixth Group Project Factors & RII\% & Rank & $\begin{array}{l}\text { Degree } \\
\text { of Effect }\end{array}$ \\
\hline Sequence of floor & $\mathbf{8 0 . 5 7 1}$ & $\mathbf{1}$ & VHE \\
\hline Site complication & $\mathbf{7 6 . 0 0}$ & $\mathbf{2}$ & HE \\
\hline Design complexity & $\mathbf{7 4 . 0 0}$ & $\mathbf{3}$ & HE \\
\hline Level of Communication & $\mathbf{6 8 . 8 6}$ & $\mathbf{4}$ & HE \\
\hline Interference & $\mathbf{6 7 . 1 4}$ & $\mathbf{5}$ & HE \\
\hline Working in confined spaces & $\mathbf{6 4 . 8 6}$ & $\mathbf{6}$ & HE \\
\hline Location of Project & $\mathbf{6 3 . 4 1}$ & $\mathbf{7}$ & HE \\
\hline $\begin{array}{c}\text { Type of activities in the } \\
\text { project }\end{array}$ & $\mathbf{5 4}$ & $\mathbf{8}$ & AE \\
\hline \multirow{2}{*}{\begin{tabular}{c} 
Result of Project Group \\
\cline { 2 - 4 }
\end{tabular}} & $\mathbf{R I I \%}$ & $\mathbf{R a n k}$ & $\begin{array}{l}\text { Degree } \\
\text { of Effect }\end{array}$ \\
\cline { 2 - 4 } & $\mathbf{6 8 . 5 7}$ & $\mathbf{6}$ & HE \\
\hline
\end{tabular}

Table (10) illustrates that the surveyed participants ranked "sequence of floor" as the most important factor that influence labor productivity in this group, with a RII of $80 \%$. This top ranked factors influence is further ranked (tenth) in its effect among all factors explored. Contrastively, the factor "Type of activities in the project" is the least important factor that influences labor productivity in this group, with a RII of $54 \%$. This group scored the sixth rank.

\subsection{Time group}

The Relative Importance Index and ranks of the eight factors are classified under the "Time Group" as shown in Table (11).

Table 11. Ranking Time Factors

\begin{tabular}{|l|c|c|c|}
\hline $\begin{array}{c}\text { Seventh Group Time } \\
\text { Factors }\end{array}$ & RII\% & Rank & $\begin{array}{l}\text { Degree of } \\
\text { Effect }\end{array}$ \\
\hline Misuse of time schedule & 75.14 & 1 & HE \\
\hline $\begin{array}{l}\text { Increasing No. of labor in } \\
\text { order to accelerate work }\end{array}$ & 70.0 & 2 & HE \\
\hline $\begin{array}{l}\text { Working for 7 days of the } \\
\text { week without the holiday }\end{array}$ & 68 & 3 & HE \\
\hline Work overtime & 66 & 4 & HE \\
\hline \multirow{2}{*}{ Result of Time Group } & RII\% & Rank & $\begin{array}{l}\text { Degree of } \\
\text { Effect }\end{array}$ \\
\cline { 2 - 4 } & 69.79 & 5 & HE \\
\hline
\end{tabular}

Table (11) illustrates that the surveyed participants ranked "Misuse of time schedule" as the most important factor that influences labor productivity in this group, with a RII of $75.14 \%$. This top ranked factors influence is further ranked (fourteenth) in its effect among all factors explored, while, the factor "Work overtime" as the least important factor influencing labor productivity in this group, with a RII of $66 \%$. This group scored the fifth rank.

\subsection{Material / Equipment group}

The Relative Importance Index and ranks of the eight factors classified under the "Material and Equipment Group" are shown in Table (12).

Table 12. Ranking Material and Equipment

\begin{tabular}{|l|c|c|c|}
\hline $\begin{array}{c}\text { Eight Group } \\
\text { Material/Equipment }\end{array}$ & $\begin{array}{c}\text { RII } \\
\%\end{array}$ & Rank & $\begin{array}{c}\text { Degree } \\
\text { of Effect }\end{array}$ \\
\hline Availability of Material & $\mathbf{8 8 . 6}$ & $\mathbf{1}$ & VHE \\
\hline $\begin{array}{c}\text { Unsuitability of materials } \\
\text { storage location }\end{array}$ & $\mathbf{7 7 . 1 4}$ & $\mathbf{2}$ & HE \\
\hline $\begin{array}{c}\text { Tool and equipment } \\
\text { shortages }\end{array}$ & $\mathbf{7 4}$ & $\mathbf{3}$ & HE \\
\hline Inefficiency of equipment & $\mathbf{6 2}$ & $\mathbf{4}$ & HE \\
\hline $\begin{array}{c}\text { Result of Material } \\
\text { Group }\end{array}$ & $\mathbf{R I I} \%$ & Rank & $\begin{array}{c}\text { Degree } \\
\text { of Effect }\end{array}$ \\
\cline { 2 - 4 } & $\mathbf{7 5 . 4 3}$ & $\mathbf{3}$ & HE \\
\hline
\end{tabular}

Table (12) illustrates that the surveyed participants ranked "availability of material" as the most important factor that influence labor productivity in this group, with a RII of $88.6 \%$. This top ranked factors influence is further ranked as (the first) in its effect among all factors explored. In contrast, the factor "Inefficiency of equipment" is the least important factor influencing labor productivity in this group, with a RII of $62 \%$. This group scored the fifth rank.

\subsection{External group}

The Relative Importance Index and ranks of the eight factors are classified under the "External Group" as shown in Table (13).

Table 13. Ranking External Factors

\begin{tabular}{|c|c|c|c|}
\hline $\begin{array}{c}\text { Ninth Group External } \\
\text { Factors }\end{array}$ & RII\% & Rank & $\begin{array}{c}\text { Degree of } \\
\text { Effect }\end{array}$ \\
\hline Weather changes & $\mathbf{8 8}$ & $\mathbf{1}$ & VHE \\
\hline Religious occasions & $\mathbf{8 6 . 2 9}$ & $\mathbf{2}$ & VHE \\
\hline Security & $\mathbf{7 8}$ & $\mathbf{3}$ & HE \\
\hline $\begin{array}{c}\text { Impact of neighboring } \\
\text { buildings }\end{array}$ & $\mathbf{7 3 . 7 1}$ & $\mathbf{4}$ & $\mathbf{H E}$ \\
\hline \multirow{2}{*}{\begin{tabular}{c} 
Result of External Group \\
\cline { 2 - 4 }
\end{tabular}} & $\mathbf{R I I \%}$ & $\mathbf{R a n k}$ & $\begin{array}{c}\text { Degree of } \\
\text { Effect }\end{array}$ \\
\cline { 2 - 4 } & $\mathbf{1}$ & VHE \\
\hline
\end{tabular}

Table (13) illustrates that the surveyed participants ranked "Weather changes" as the most important factor influencing labor productivity in this group, with a RII of $88 \%$. This top ranked factor's influence is further ranked as (second) in its effect among all factors explored, while, the factor "Impact of neighboring buildings" as the least important factor influence labor productivity in this group, with a RII of $73.71 \%$. This group scored the first rank. 


\section{The ten Most influential factors on labor productivity (using the fishbone technique)}

A Fishbone diagram, also called a cause and effect diagram or Ishikawa diagram, is a visualization tool for categorizing the potential causes of a problem in order to identify its root causes.

Table (14) and Figure (1) show the results of the most influential factor in productivity through the results of the survey. It is found that the highest factor affecting is the "availability of materials in the project" and the value of the Relative Importance of this Index is (88.571\%), while the factor that occupies the tenth position in the ranking is the floor of the sequence and the value of the Relative Importance Index (80.571\%).

Table 14. The ten most influence factors on labor productivity

\begin{tabular}{|c|c|c|c|c|}
\hline Rank & Factors Affect & Degree of Effect & RII \% & Related Group \\
\hline 1 & Availability of Material & VHE & 88.571 & Material/Equipment \\
\hline 2 & Weather changes & VHE & 88.00 & External \\
\hline 3 & Religious occasions & VHE & 86.286 & External \\
\hline 4 & Number of working groups & VHE & 86.00 & Workforce \\
\hline 5 & Ganger experiences & VHE & 85.714 & Workforce \\
\hline 6 & Lack of Workforce surveillance & VHE & 84.857 & Leadership \\
\hline 7 & Ganger age & VHE & 84.00 & Workforce \\
\hline 8 & Working at high place & VHE & 82.00 & Safety \\
\hline 9 & Drawings and specifications alteration during execution & VHE & 81.690 & Supervisors \\
\hline 10 & Sequence of the floor & VHE & 80.571 & Project \\
\hline
\end{tabular}

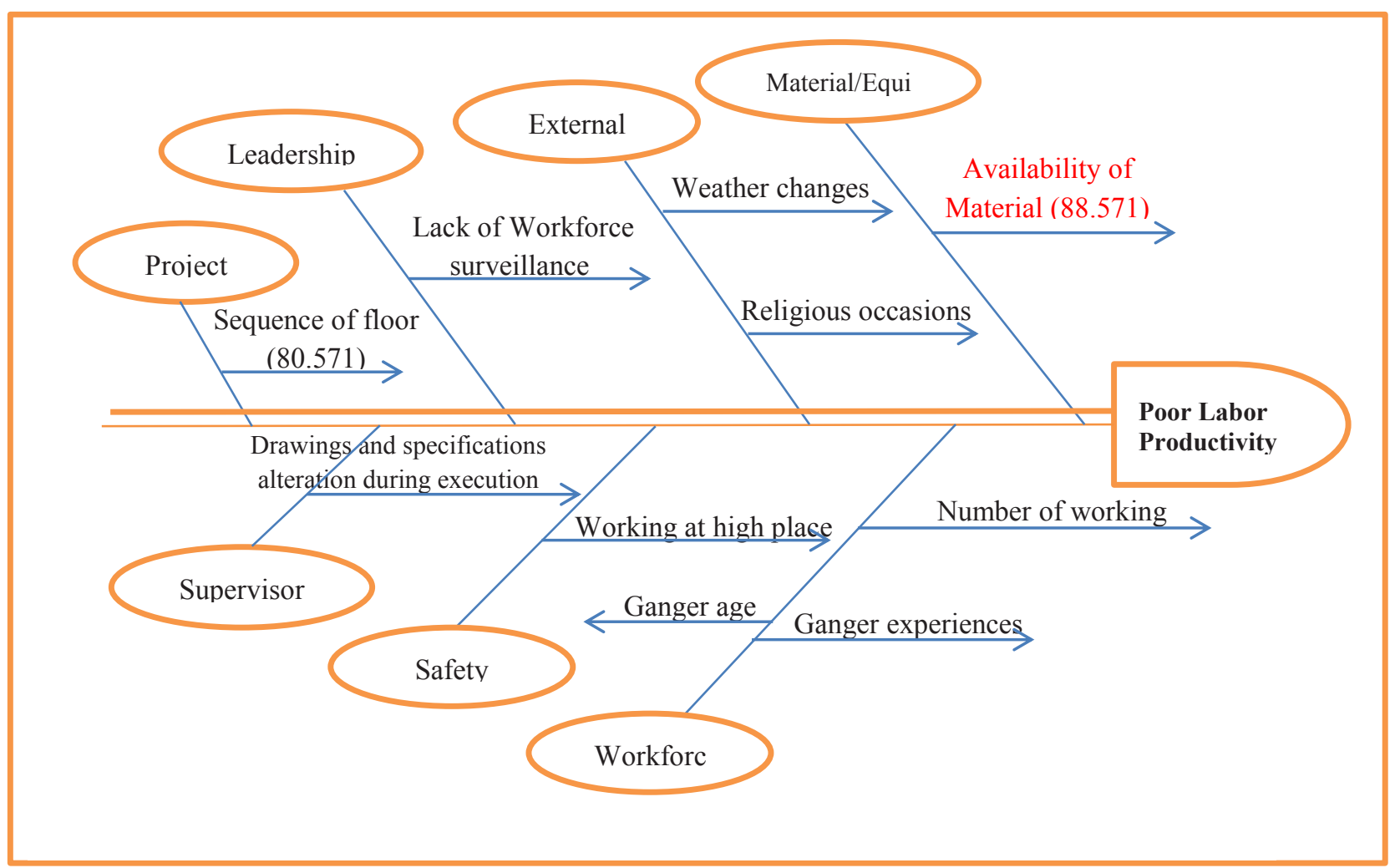

Fig 1. shows the ten most influence factors on productivity (Using a Fishbone Technique) 


\section{Groups ranking}

The 42 identified factors are grouped into nine groups. The ranking of these groups is associated with importance as assessed by engineers who work in the construction sector in Iraq.
Figure (2) indicates that the top important group affecting labor productivity in public construction is External, Supervisors, Material/Equipment, Workforce, Time, Project, Leadership, Motivation and Safety respectively.

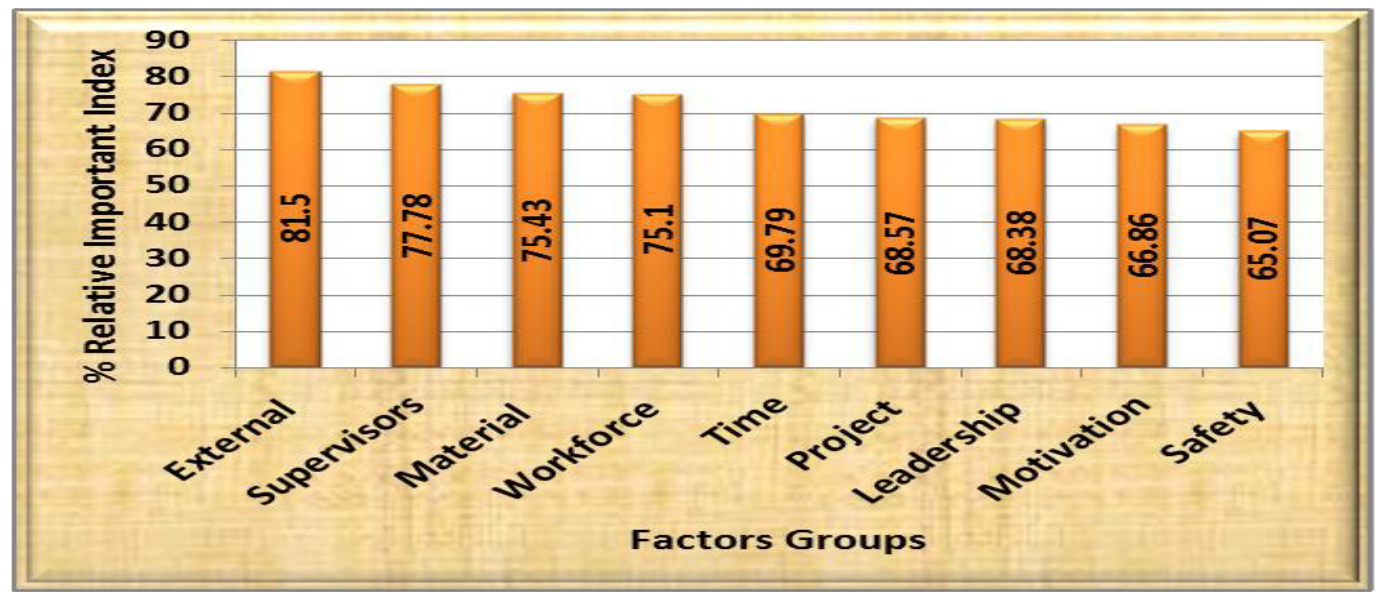

Fig 2. Main groups ranking

\section{Overall ranking factors}

Relative Importance Index and ranking of all investigated 42 factors that affect labor productivity in the construction sector in Iraq are listed in Table (15). The analysis clarifies the followings: (1) there are 10 factors with importance index higher than $80 \%$, (2) the minimum importance index is $54 \%$. These indicate that the identified factors are highly relevant to the problem of labor productivity in public and private construction sectors in Iraq. Table (15) shows that the top ten important factors affecting labor productivity in public and private construction projects in Iraq among engineers who work in the construction sector. They are ordered as follows: (1) Availability of Material, (2) Climate status "Weather changes", (3) Religious occasions, (4) Number of working groups, (5) Ganger experiences, (6) Lack of Workforce surveillance, (7) Ganger age, (8) Working at a high place, (9) Drawings and specifications alteration during execution, and (10) Sequence of floor.

\section{Conclusions and recommendations}

The objective of this study was to identify the factors that influence labor productivity in construction projects in Iraq. In this study, it was found that forty two factors negatively affect labor productivity.

The most important, namely:

1. Availability of Material;

2. Climate status "Weather changes";

3. Religious occasions;

4. Number of working groups;

5. Ganger experiences;

6. Lack of Workforce surveillance;
7. Ganger age;

8. Working at high place;

9. Drawings and specifications alteration during execution; 10. Sequence of floor;

Moreover, 42 factors considered in the study were divided into nine groups, which were ranked according to their Relative Importance Index:

1. External factors group.

2. Supervision factor group.

3. Material / Equipment factor group.

4. Workforce factors group.

5. Time factor group

6. Project factor group.

7. Leadership factors group.

8. Motivation factor group.

9. Safety factor group

Based on the results of this study, the next actions recommended are:

1. Provide appropriate scheduling and programming taking into consideration period in demand for the supply of materials.

2. Choosing a suitable storage location for purchasing materials in any project, which should be easy, accessible and close to / near the work sites.

3. In order to have improved site management, the construction teams should have more communication and coordination during all project stages.

4. It is needful to employ project scheduling techniques (such as computer-aided construction project management) in each project to optimize the times of regarding activities, and to ensure that works allow continuous job performance. 
5. Site inspections must be conducted permanently during the project design phase to avoid design changes during the implementation phase.

\section{References}

1. S. Hafez, R. Aziz, E. Morgan, M. Abdullah, And E. Ahmed, , American Journal of Civil Engineering, 2 (2): 35-40 (2014).

2. S. Wilcox, B. String fellow, R. Harris, and B. Martin, Transportation research board, committee on management and productivity. Washington, USA, (2000).

3. D. Sumanth, McGraw-Hill, New York, (1984).

4. C. Peles, Transaction of the American Association of Cost Engineers, 31st Annual Meeting, Atlanta, USA, (1987).

5. V. Handa, and O. Abdalla, Construction Management and Economics, 7 (1): 19-28 (1989).

6. M. R. Finke,. Journal of Construction Engineering Management, 124 (6): 490-497 (1998).

7. E. Allmon, C. Hass, J. Borcherding, and P. Goodrum, Journal of Construction Engineering and Management, 126 (2): 97-104 (2000).

8. R. M. W. Horner, and R. Duff, Construction Industry Research and Information Association (CIRIA), London, UK, (2001).

9. P. Olomolaiye, A. Jayawardane, And F. Harris, Chartered Institute of Building, UK, (1998).

10. R. M. W. Horner, B. T. Talhouni, and H.R. Thomas, Proc. Of the 3rd Yugoslavian Symp. On Construction Management, Cavtat, 18-28 (1989).

11. E. C. Lim, and J. Alum, International Journal of Project Management, 13 (1): 51-58 (1995).

12. P. Kaming, P. Olomolaiye, G.D. Holt., and F. Harris, International Journal of Project Management, 15(1): 21-30, (1997).

13. A. Makulsawatudom, M. Emsley, and K. Sinthawanarong, Journal of King Mongkut's Institute of Technology North Bangkok, 14 (3), 1-6, (2004).

14. H. M. Alinaitwe, J. A. Mwakali, and B. Hansson, Journal of Civil Engineering and Management, XIII (3): 169-176, (2007).

15. A. Soekiman, K. Pribadi, B. Soemardi, R. Wirahadikusumah, The Twelfth East Asia-Pacific Conference on Structural Engineering and Construction, proceed Engineering 14, 865-873, (2011).

16. T. G. Shree Raja Gopal, K. Murali International Journal of Recent Scientific Research. Vol 7, Issue, 6, pp.11744-11747, (2016).

17. A. Jarkas, and G. Bitar, Journal of Construction Engineering and Management, ASCE, 138 (7): 811 820, (2012).
18. M. Zakeri, P. Olomolaiye, G. Holt and F. Harris, Construction Management and Economics, 14 (5), 417-26, (1996).

19. S. Durdyev, S. Ismail, and N. Abu Bakar,. Razak School of Engineering and Advanced Technology, University Technology Malaysia, International Campus, Jalan Semarak, 54100, Kuala Lumper, Malaysia. DOI: 10.7763/IPEDR. V55. 1, (2012).

20. I. Mahamid, Contractors' Perspective. International Journal of Architecture, Engineering and Construction (IJAEC), 2 (3): 194 - 202, (2013).

21. G. Bekr, DOI: 10.5176/2301-394X_ACE16, (2016).

22. N. Ailabouni, K. Gidado, and N. Painting, Proceeding Conference for Postgraduate Researchers of the Built and Natural Environment (PRoBE), Glasgow, United Kingdom, 33-46, (2007).

23. A. Enshassi, S. Mohamed, Z. Abu Mustafa, And P.E. Mayer, Journal of Civil Engineering and Management, 13 (4): 245-254, (2007).

24. W. Alaghbari, A. Salim, K. Dola, and A. Ali, International Journal of Housing Markets and Analysis, 5 (1): 41-52, (2012).

25. G. Schroder, Roger, Mc Graaw - Hill Company (1981).

26. J. Prkopenko, , ILO, Geneva, (1993).

27. Z. Herbsman, and R. Ellis, Construction. Management. Econ., 8 (1), 49-61, (1990).

28. B.T Talhouni, Ph.D. thesis, Dept. of Civil Engineering, Univ. Of Dundee, Dundee, UK, (1990).

29. G. Brent Hickson and A. Leighton Ellis, The Journal of the Association of Professional Engineers of Trinidad and Tobago, 2 (1), 4-11, (2014).

30. G. Robels, International Journal of Civil, Environmental, Structural, Construction and Architectural Engineering, 8 (10), 1021-1030, (2014).

31. S. Durdyev, And S. Ismail, Scientific Research and Essays, 7 (4): 824-833, (2012).

32. R. Hogg, And E. Tannis,. 8th Ed., Prentice Hall, Upper Saddle River, NJ, (2009).

33. S. Abu Shaban,. MSc Thesis, Islamic University of Gaza, Construction Management Department, Palestine, (2008). 
Table 15. The Overall ranking of factors that negatively affecting labor productivity

\begin{tabular}{|c|c|c|c|c|c|c|c|c|}
\hline \multirow{3}{*}{$\overrightarrow{\mathbb{\Xi}}$} & \multirow{3}{*}{ Factors Affecting Labor Productivity } & \multirow{2}{*}{\multicolumn{5}{|c|}{$\begin{array}{c}\begin{array}{c}\text { Number of } \\
\text { Respondents scoring }\end{array} \\
\text { Impact }\end{array}$}} & \multirow{3}{*}{ RII \% } & \multirow{3}{*}{$\begin{array}{l}\bar{D} \\
\stackrel{0}{=}\end{array}$} \\
\hline & & & & & & & & \\
\hline & & LE & SE & $\mathbf{A E}$ & HE & VHE & & \\
\hline 1 & Availability of Material & 1 & 2 & 6 & 18 & 43 & 88.571 & 1 \\
\hline 2 & Climate status "Weather changes" & 0 & 1 & 13 & 13 & 43 & $\mathbf{8 8 . 0 0}$ & 2 \\
\hline 3 & Religious occasions & 1 & 1 & 15 & 11 & 42 & 86.286 & 3 \\
\hline 4 & Number of working groups & 1 & 1 & 12 & 18 & 38 & 86.00 & 4 \\
\hline 5 & Ganger experiences & 1 & 2 & 9 & 22 & 36 & 85.714 & 5 \\
\hline 6 & Lack of Workforce surveillance & 1 & 2 & 10 & 23 & 34 & 84.857 & 6 \\
\hline 7 & Ganger age & 1 & 4 & 10 & 20 & 35 & 84.00 & 7 \\
\hline 8 & Working at high place & 0 & 0 & 20 & 23 & 27 & 82.00 & 8 \\
\hline 9 & Drawings and specifications alteration during execution & 0 & 1 & 17 & 28 & 25 & 81.690 & 9 \\
\hline 10 & Sequence of the floor & 0 & 0 & 23 & 22 & 25 & 80.571 & 10 \\
\hline 11 & Rework & 1 & 2 & 21 & 19 & 27 & 79.71 & 11 \\
\hline 12 & Payment delay & 1 & 4 & 23 & 15 & 27 & 78.00 & 12 \\
\hline 13 & Security & 1 & 3 & 21 & 22 & 23 & 78.00 & 12 \\
\hline 14 & Supervisors absenteeism & 1 & 3 & 24 & 17 & 25 & 77.71 & 13 \\
\hline 15 & Unsuitability of materials storage location & 2 & 2 & 25 & 16 & 25 & 77.14 & 14 \\
\hline 16 & Site complication & 3 & 4 & 15 & 30 & 18 & 76.00 & 15 \\
\hline 17 & Number of assistant workers & 3 & 3 & 22 & 20 & 22 & 75.71 & 16 \\
\hline 18 & Misuse of time schedule & 2 & 4 & 24 & 19 & 21 & 75.14 & 17 \\
\hline 19 & Design complexity & 1 & 3 & 30 & 18 & 18 & 74.00 & 18 \\
\hline 20 & Tool and equipment shortages & 2 & 3 & 25 & 24 & 16 & 74.00 & 18 \\
\hline 21 & Impact of neighboring buildings & 2 & 3 & 25 & 25 & 15 & 73.71 & 19 \\
\hline 22 & Disloyalty & 3 & 6 & 24 & 20 & 17 & 72.00 & 20 \\
\hline 23 & Inspection delay & 2 & 4 & 29 & 20 & 15 & 72.00 & 20 \\
\hline 24 & Increasing No. of labor in order to accelerate work & 1 & 4 & 32 & 13 & 17 & 70.00 & 21 \\
\hline 25 & Financial motivation system & 3 & 4 & 29 & 16 & 18 & 70.00 & 21 \\
\hline 26 & Level of Communication & 4 & 7 & 31 & 10 & 18 & 68.86 & 22 \\
\hline 27 & Working for 7 days of the week without the holiday & 4 & 7 & 30 & 15 & 14 & 68.00 & 23 \\
\hline 28 & Interference & 5 & 10 & 25 & 15 & 15 & 67.14 & 24 \\
\hline 29 & Work overtime & 5 & 7 & 30 & 18 & 10 & 66.00 & 25 \\
\hline 30 & Misunderstanding between Workforce and superintendents & 4 & 6 & 37 & 14 & 9 & 65.14 & 26 \\
\hline 31 & Working in confined spaces & 2 & 8 & 39 & 13 & 8 & 64.86 & 27 \\
\hline 32 & Location of Project & 4 & 8 & 38 & 11 & 9 & 63.71 & 28 \\
\hline 33 & Moral Motivation system & 5 & 12 & 31 & 10 & 12 & 63.43 & 29 \\
\hline 34 & Lack of competition & 7 & 11 & 28 & 11 & 13 & 63.43 & 29 \\
\hline 35 & Inefficiency of equipment & 6 & 10 & 34 & 11 & 9 & 62.00 & 30 \\
\hline 36 & Accidents & 4 & 12 & 38 & 8 & 8 & 61.14 & 31 \\
\hline 37 & Misunderstanding among Workforce & 8 & 10 & 31 & 15 & 6 & 60.29 & 32 \\
\hline 38 & Unemployment of safety officer at construction site & 10 & 7 & 36 & 9 & 8 & 59.49 & 33 \\
\hline 39 & Violation of safety precautions & 7 & 14 & 35 & 8 & 6 & 57.71 & 34 \\
\hline 40 & Lack of periodic meeting with Workforce & 11 & 12 & 35 & 7 & 5 & 55.14 & 35 \\
\hline 41 & Lack of training sessions & 11 & 16 & 30 & 9 & 4 & 54.00 & 36 \\
\hline 42 & Type of activities in the project & 10 & 16 & 33 & 7 & 4 & 54.00 & 36 \\
\hline
\end{tabular}

